\title{
REGIONAL GEOLOGY AND THRUST FAULT TECTONICS IN THE SOUTHERN PART OF THE NORTH GREENLAND FOLD BELT, NORTH PEARY LAND
}

\author{
Stig A. Schack Pedersen
}

\section{Introduction}

The purpose of this article is to give a preliminary geological description of the southwestern part of Johannes $V$. Jensen Land, and in particular the development of an early phase of thrust fault structures.

The area investigated lies south of the Harder Fjord fault between Midtkap in the east and Kap Holger Danske in the west; the southern limit is a line following Frederick E. Hyde Fjord, Nordpasset and O. B. Bøggild Fjord. The area is transected by a few major E-W trending and $\mathrm{N}-\mathrm{S}$ trending valley systems, between which mountains rise steeply to a height of $c .1000 \mathrm{~m}$. In the western part of the area the mountains are covered by a number of smaller ice caps (fig. 37).

The rocks within the area are Lower Palaeozoic clastic trough sediments belonging to the North Greenland (Franklinian) geosyncline (Dawes, 1976). In Devonian-Carboniferous time they were affected by intense deformation which gave rise to the North Greenland fold belt. The studied area lies at the south margin of the fold belt, and although deformation is sometimes intense the rocks are unmetamorphosed.

The general E-W trend of the North Greenland fold belt has been known since 1916 (Koch 1920), and the curving of trend lines from $\mathrm{E}-\mathrm{W}$ to $\mathrm{N}-\mathrm{S}$ in the area between Frederick E. Hyde Fjord and Nornegast Dal (fig. 37) was mapped from aerial photographs by J. Haller in 1961 (Haller, 1971); the latter did not receive special attention before 1979. By the end of the 1979 field season the curved lineaments could be shown to be the result of an early phase of thrust fault tectonics, not previously recognised, superimposed by later E-W folding.

\section{Stratigraphy}

The following stratigraphical units have been recognised (fig. 37).

The Frigg Fjord mudstones (Fränkl, 1955; Dawes \& Soper, 1973) is the lowest recognisable unit. The formation consists of green, red, and in the lowest part yellow coloured laminated claystones or mudstones. Due to tectonism it breaks into brittle pieces, but no distinct cleavage has been observed. Undisturbed sections have not been seen and the thickness is estimated to be of the order of 100 to $200 \mathrm{~m}$ (half as much as the estimate of Fränkl, 1955). The Frigg Fjord mudstones make up the beautifully coloured hills around Frigg Fjord (fig. 37) and the lowlands and valleys between Nornegæst Dal and Frederick E. Hyde Fjord. In addition they are often incorporated in the thrust sheets, especially in the northwestern part of the area. The Frigg Fjord mudstones grade up into dark shales and distal turbidites which form a link to the succeeding formation A.

Formation A (Dawes \& Soper, 1979) consists of a series of quartzitic sandstone turbidites 


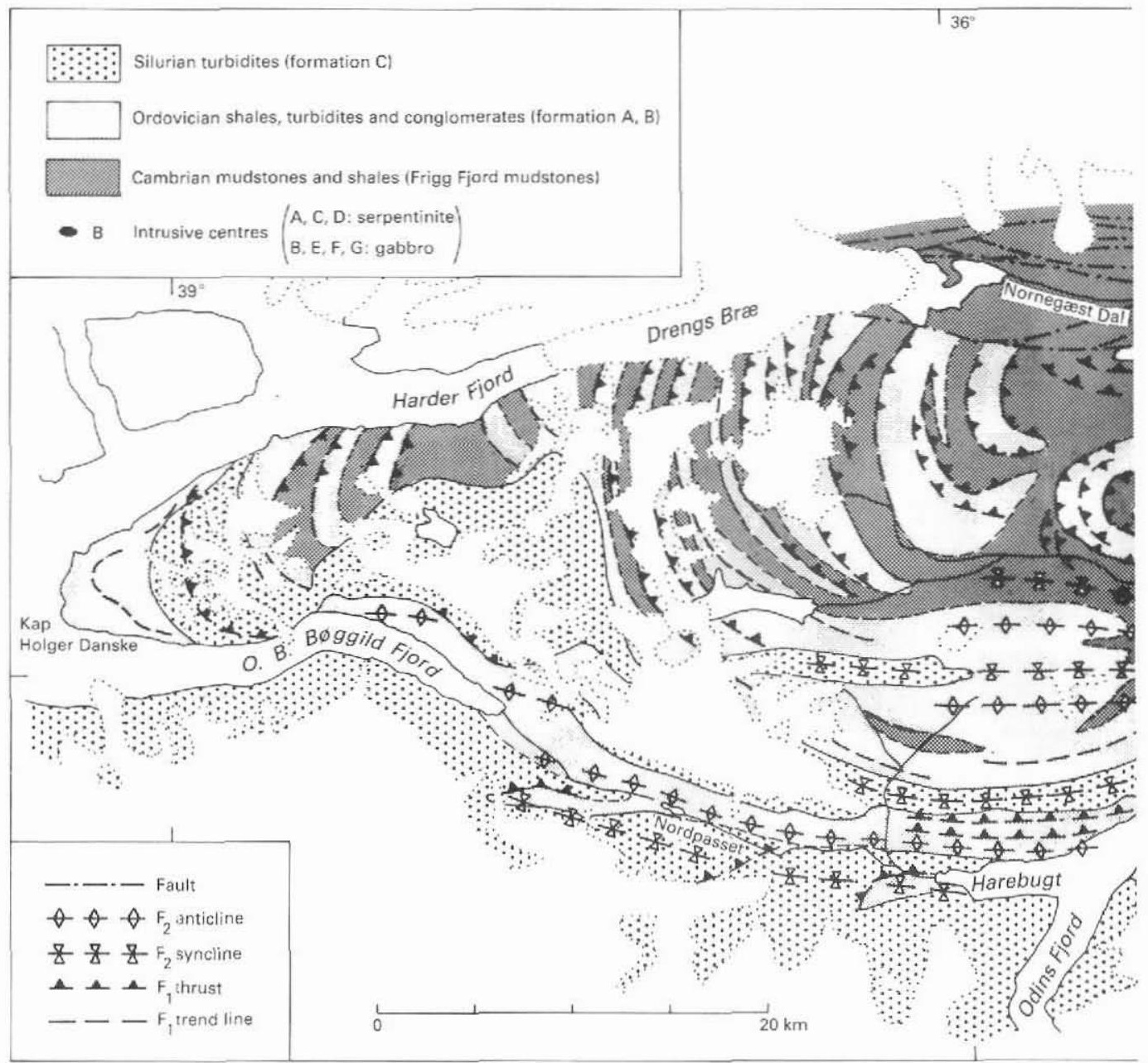

Fig. 37. Geological map of the southern part of Johannes V. Jensen Land, North Peary Land, North Greenland. Intrusive centres see also fig. 41.

intercalated with calcareous turbidites and cherty shales. The thickness varies from about $500 \mathrm{~m}$ in the western part of the area to $250 \mathrm{~m}$ in the eastern part. On top of the turbidites there is a conglomerate level that formed a characteristic competent layer during deformation. The high mountains in the central and western part of the area are built up of thrust sheets displaying more or less complete sections of formation A.

In the area between Kap Mjølner and Harebugt (fig. 37) a c. $100 \mathrm{~m}$ thick sequence of thick-bedded, clast-supported, coarse-grained limestone-conglomerates appear. The precise stratigraphical position of the unit is difficult to determine because it is bounded by thrust faults, but it is thought to be situated in the upper part of formation A or in the lower part of 


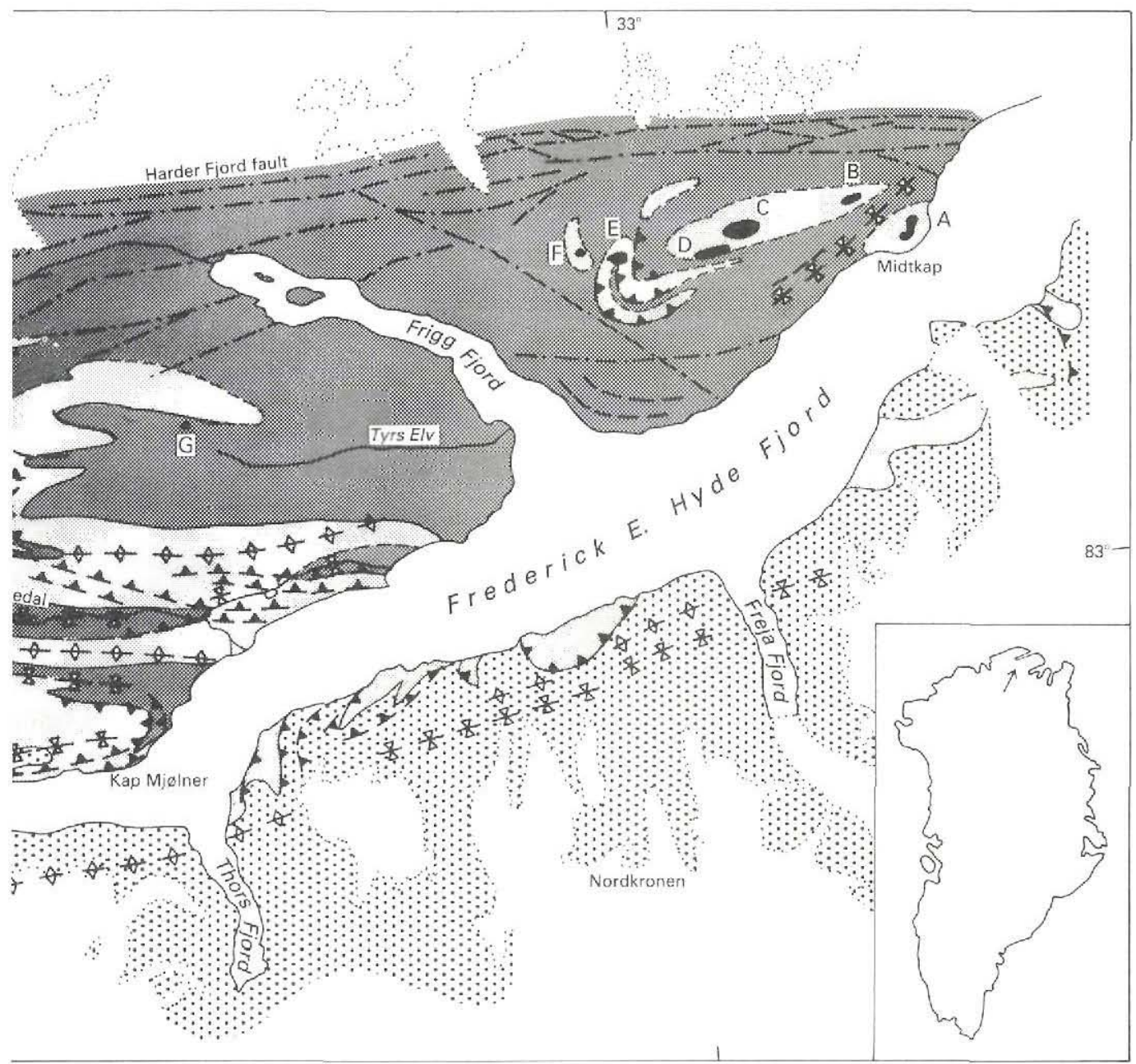

formation B (see below). In the following the unit is informally referred to as the Kap Mjølner limestone-conglomerate.

Formation B (Dawes \& Soper, 1979) is a dark shale and green cherty shale unit overlying formation $\mathrm{A}$. The cherty shales are often rusty coloured and intercalated with shale-clast conglomerates. The thickness of this unit is c. $300 \mathrm{~m}$, but it is often very difficult to determine exactly due to intensive chevron-type folding of the uniformly bedded shales and chertified shales. Graptolites collected by Dawes \& Soper in 1969 at Harebugt give the unit an Arenig age (Bjerreskov \& Poulsen, 1973).

Formation C (Dawes \& Soper, 1979) is the uppermost stratigraphical unit in the area. It 
consists of several hundred metres of uniform Silurian turbidites that can be correlated with the un-named Silurian flysch formation (Christie \& Peel, 1977) of the Børglum Elv region $50 \mathrm{~km}$ to the south. A coarse clastic limestone-conglomerate occurs $c .100 \mathrm{~m}$ up in the formation. In the area north of Nordpasset this horizon is only $10 \mathrm{~m}$ thick, but to the south and southeast, in the Freja Fjord area (fig. 37) (Pedersen, 1979) and in the Citronens Fjord area, $40 \mathrm{~km}$ east of Midtkap, the unit consists of two or three limestone-conglomerate beds of which the lowermost can be up to $25 \mathrm{~m}$ thick.

\section{Intrusive rocks}

Two different categories of intrusive rocks occur in the area: (a) a group of small intrusions west of Midtkap; (b) two generations of basic dykes, one intra-deformational and the other post-orogenic.

\section{Intrusions west of Midtkap}

The easternmost occurrence is at Midtkap where a body of serpentinite has been involved in the thrusting and folding (fig. 37). (This is intrusion A of fig. 41 in Soper et al., this report.) On the steepest peak of Midtkap a $c .150 \mathrm{~m}$ thick, $\mathrm{N}-\mathrm{S}$ striking, vertical sheet of dark green serpentinite breccia appears. The blocks in the breccia are up to $30 \mathrm{~cm}$ across, commonly with rounded shape, and occur in an altered chlorite matrix. Cross-cutting shear zones consist of glassy serpentinite often showing slicken-side structures. At the top of the mountain a $c .5 \mathrm{~m}$ wide body of granodiorite occurs as a xenolith in the serpentinite.

Intrusions B-F (fig. 37) include gabbros and intrusive centres and are described by Soper et al. (this report).

The westernmost intrusion is situated $c .8 \mathrm{~km}$ southwest of Frigg Fjord and $2 \mathrm{~km}$ north of Tyrs Elv (fig. 37). Here a c. $10 \mathrm{~m}$ thick sheet of layered gabbro occurs in Frigg Fjord mudstones. The layering is rather thin with an alternation between 1 to $5 \mathrm{~cm}$ dark, medium-grained, pyroxene cumulates and 3 to $10 \mathrm{~cm}$ thick, light plagioclase bands. Below the gabbro a fine-grained basaltic breccia occurs with baked pieces of Frigg Fjord mudstones and siderite phenocrysts. In the mudstone xenoliths and in veins in the surrounding Frigg Fjord mudstones, haematite and epidote are common.

The association of the two intrusions, described above, with $F_{1}$ thrust structures suggests they were emplaced in the lower Upper Palaeozoic, although Soper et al. (personal communication, 1980) did not observe such relationships with intrusions B-F which they presume to be later in age.

\section{Basic dykes}

The oldest generation of basic dykes forms a curved linear pattern through the central part of the area. The dykes are only a few metres wide and displaced by low angle thrust faults accompanying the second phase of deformation. The dykes seems to be unaffected by the first phase of deformation. The dykes are doleritic, and often contain xenocrysts of carbonate.

The youngest generation of dykes trends E-W and has been mainly observed in the area 
north and south of Frederick E. Hyde Fjord and Nordpasset. Dawes \& Soper in 1969 collected a dyke sample south of $\mathrm{O}$. B. Bøggild Fjord which gave a K/Ar date fo $66 \mathrm{~m} . \mathrm{y}$. (GGU 53487) (Dawes, 1971). The dykes are doleritic and range in thickness from $20 \mathrm{~cm}$ to a few metres. They cross-cut all the deformation structures, but can often be seen to follow zones of weakness such as steeply inclined thrust faults and vertical bedding.

\section{Structural geology}

Two deformation phases have been recognised. The first phase $\left(F_{1}\right)$ is represented by WSW verging overturned folds and westward directed thrust faults. The second phase $\left(F_{2}\right)$ is represented by major $\mathrm{E}-\mathrm{W}$ trending folds related to the main deformation of the North Greenland fold belt and formed by $\mathrm{N}-\mathrm{S}$ compression.

\section{First phase structures $\left(F_{1}\right)$}

The first phase structures are characterised by spectacular thrust faults and associated thrust folds. The $F_{1}$ thrust planes were initially flat lying or slightly eastward dipping, although now, mainly, have steep dips due to $F_{2}$ refolding. The thrust folds all indicate a relative westward movement of successive thrust sheets with substantial and often measurable displacement. The thrusts are most conspicuously developed in formation A, typically with thin developments of Frigg Fjord mudstones at the base of the thrust sheets. Traced eastwards and downwards, the thrusts pass into incompetent Frigg Fjord mudstones which presumably acted as a zone of décollement. At higher stratigraphic levels the thrusts are difficult to trace and may be replaced by folding.

The structures were first noticed in 1978 (Pedersen, 1979), and subsequently, photogeological studies were made in the spring of 1979 using a Kern PG2 photogrammetric instrument. Field studies in summer 1979 included the following localities: (1) east of Kap Mjølner; (2) north of Harebugt; (3) south of Drengs Bræ; (4) north of Vølvedal (fig. 37).

\section{East of Kap Mjølner}

About $10 \mathrm{~km}$ east of Kap Mjølner, on the north side of Frederick E. Hyde Fjord, the tectonic style of the thrust fault deformation is well seen in a $6 \mathrm{~km}$ long and $500 \mathrm{~m}$ high cliff section. Here four thrust sheets can be recognised. The thickness of the sheets is 200 to 250 $\mathrm{m}$ and the displacement is less than $1 \mathrm{~km}$ in the uppermost thrust faults in the east, but increases to $3 \mathrm{~km}$ in the lowermost thrust fault to the west (fig. 38). Two of the thrust sheets have developed very characteristic anticlinal thrust folds with fold axes plunging steeply to the NNW due to tilting by the later $F_{2}$ deformation. The rocks incorporated in the deformation are chiefly formation $\mathrm{A}$. The top conglomerate of the turbidite sequence forms a characteristic light band outlining distinctly the internal structure in the thrust sheet. At the bottom of the sheets, up to $10 \mathrm{~m}$ of the Frigg Fjord mudstones may be present. At the top of the sheets the shales of formation $B$ have been intensively chevron folded. In these rocks it is difficult to follow the precise continuation of the thrust faults. Due to displacement-compensation through folding they may cease to exist as suggested, by Thompson (1979), for similar structures in the northern Rocky Mountains. 


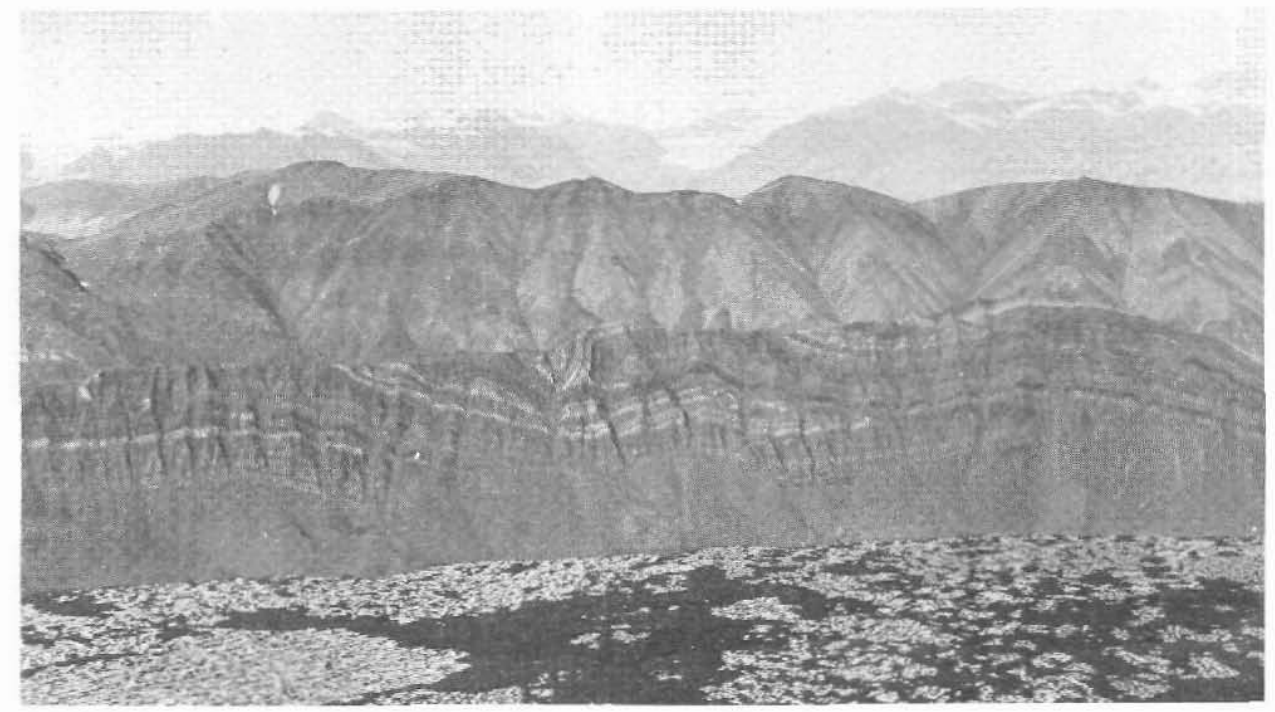

Fig. 38. Coast cliff section on the north side of Frederick E. Hyde Fjord between Kap Mjølner and Frigg Fjord. The profile is orientated W-E viewed from the south, approximately perpendicular to the fold axes of the thrust sheet anticlines. White band on top of the sheets is the top conglomerate of formation A. Profile height is approximately $500 \mathrm{~m}$.

\section{North of Harebugt}

Along the north coast of Frederick E. Hyde Fjord the Kap Mjølner limestoneconglomerate can be followed from Kap Mjølner to Harebugt. At Kap Mjølner this unit is repeated in three thrust sheets with displacements of more than $5 \mathrm{~km}$. West of Kap Mjølner the structures become very complex due to later deformation and post-orogenic faulting. However, north of Harebugt several thrust fault planes can be distinguished through the appearance of two anticlinal thrust folds (fig. 39). The southernmost fold is outlined by the conglomerate at the top of formation $\mathrm{A}$. This unit can be followed continuously for more than $5 \mathrm{~km}$ to the east. The northernmost anticline is defined by the Kap Mjølner limestone-conglomerate, and this limestone-conglomerate unit can be followed continuously for more than $10 \mathrm{~km}$ to the east, before the limestone-conglomerate in the underlying sheet shows a structure that can be interpreted as a synclinal thrust fold. This gives a displacement of the order of 5 to $10 \mathrm{~km}$. The refolded anticlines have steep NNW plunging axes.

\section{South of Drengs Brae}

The best exposed cross-section through the structures responsible for the N-S trending mountain ridges between Vølvedal and Harder Fjord - Nornegæst Dal is the steep cliff south of Drengs Bræ. More than five thrust sheets can be seen here, superimposed on each other. The thickness of each sheet is about $100 \mathrm{~m}$ and the thrust faults are steeply inclined with dips of more than $70^{\circ}$. The rocks involved in the deformation are Frigg Fjord mudstones and the 


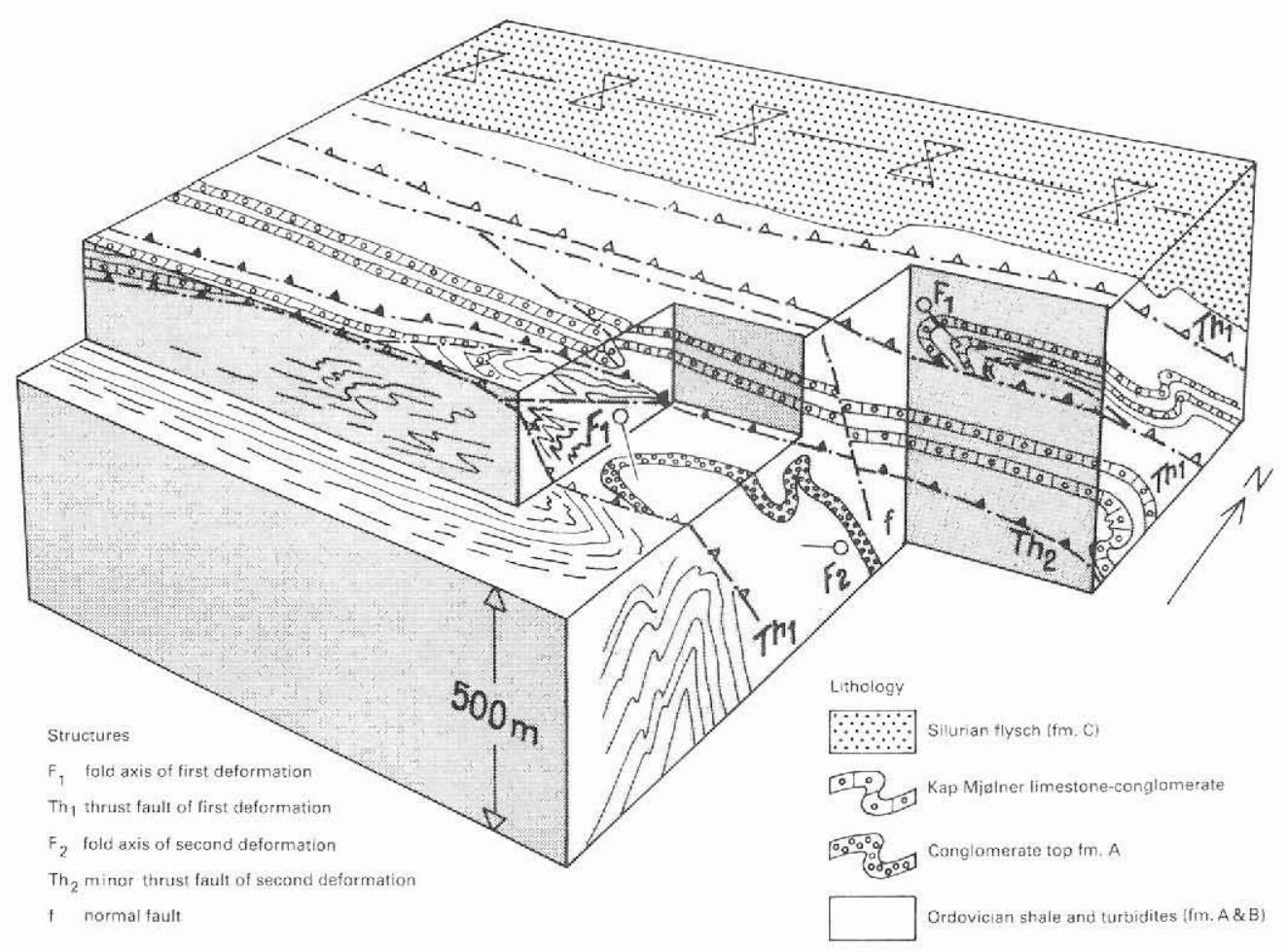

Fig. 39. Block diagram illustrating the thrust fault and fold structures north of Harebugt. The $F_{1}$ thrust fault planes are oriented $\mathrm{E}-\mathrm{W}$ with steep dips to the north due to reorientation by the $\mathrm{F}_{2}$ folding.

lower parts of formation A. A competent unit of grey cherty shale and distal-type turbidites outlines the synclinal thrust folds very clearly. To the south these thrust sheets overthrust formation $\mathrm{C}$ turbidites along a steeply dipping thrust fault striking $\mathrm{N}-\mathrm{S}$.

\section{North of Vølvedal}

In the mountains north of Vølvedal and southwest of Tyrs Elv recumbent $F_{1}$ fold structures appear. The amplitude of the tight to isoclinal, overturned anticlines is about $1000 \mathrm{~m}$, and the axes trend $\mathrm{N}-\mathrm{S}$. Here, on a mountain slope facing Vølvedal, the only lunar structure in the area was observed. The structure is rather complex because thrusting occurs in the cores of the $\mathrm{F}_{1}$ folds.

\section{Dating of the $F_{I}$ deformation}

The youngest observed sedimentary rocks incorporated in the thrust fault deformation are the lower part of the Silurian turbidite sequence which are now known to range from, at least, Early Llandovery to, probably, Ludlow age in Peary Land (Hurst \& Surlyk, this report 
and personal communication, 1980). The upper age limit of the deformation is determined by the Upper Carboniferous Foldedal and Kim Fjelde Formations, which overlie the Franklinian rocks with a regional uncomformity in eastern Peary Land (Håkansson, 1979). It is therefore suggested that the first phase of deformation in the southern part of the fold belt took place between late Silurian and late Carboniferous time.

\section{Second phase structures $\left(F_{2}\right)$}

The E-W trending folds of the area studied have earlier been referred to as the fold belt deformation phases $F_{1}$ and $F_{2}$ by Dawes \& Soper $(1973,1979)$.

Two different fold styles have been distinguished. In the central part of the area the folds are open to close upright folds that become slightly overturned to the north in the northern part of the area. In the southern part of the area the developed structures are large overturned southward verging folds (Pedersen, 1979). This deformation is connected with southward directed thrust faulting and a weakly developed north dipping cleavage has been formed locally. In the central and northern part of the area box fold structures are often developed during the $F_{2}$ deformation.

The large scale synforms and antiforms produced during $F_{2}$ deformation have an amplitude of $500 \mathrm{~m}$ and a wave-length of 2 to $3 \mathrm{~km}$. Where the second deformation interfers with the first deformation, very intensive folding and complex structures appear. On the flanks of the $F_{2}$ folds all $F_{1}$ structures have been reorientated into steeply inclined positions. At a locality between Kap Mjølner and Harebugt, reactivation along the old thrust planes, but in a new direction, can be documented by drag folds. This deformation mechanism is thought to have been common during the $F_{2}$ phase.

In the regional structural framework, $F_{2}$ deformation is responsible for the major bending of $F_{1}$ structures which formed the curved trend lines seen on fig. 37.

\section{Conclusions}

The southern part of the North Greenland fold belt in southern Johannes V. Jensen Land has been affected by two phases of deformation. An early phase of westward directed thrusting and folding which in some respect resembles thin-skinned décollement tectonics. The second phase of deformation is coaxial with, and forms part of, the main E-W trending fold structures of the North Greenland fold belt which are formed by $\mathrm{N}-\mathrm{S}$ compression. The characteristic curved trend lines in the area are formed by interference between the early thrust fault structures and the later folding.

Some of the intrusive rocks west of Midtkap seem to be associated with $F_{1}$ thrust sheets and have apparently been emplaced in early Upper Palaeozoic time.

A group of ENE striking basic dykes were intruded after $F_{1}$ deformation and before $F_{2}$ deformation. E-W trending dolerite dykes post-date $\mathbf{F}_{\mathbf{2}}$.

\section{References}

Bjerreskov, M. \& Poulsen, V. 1973: Ordovician and Silurian faunas from northern Peary Land, North Greenland. Rapp. Grønlands geol. Unders. 55, 10-14. 
Christie, R. L. \& Peel, J. S. 1977: Cambrian - Silurian stratigraphy of Børglum Elv, Peary Land, eastern North Greenland. Rapp. Grønlands geol. Unders. 82, $48 \mathrm{pp}$.

Dawes, P. R. 1971: The North Greenland fold belt and environs. Bull. geol. Soc. Denmark 20, 197-239.

Dawes, P. R. 1976: Precambrian to Tertiary of northern Greenland. In Escher, A. \& Watt, W. S. (edit.) Geology of Greenland, 248-303. Copenhagen: Geol. Surv. Greenland.

Dawes P. R. \& Soper, N. J. 1973: Pre-Quaternary history of North Greenland. In Pitcher, M. G. (edit.) Arctic Geology. Mem. Amer. Ass. Petrol. Geol. 19, 117-134.

Dawes, P. R. \& Soper, N. J. 1979: Structural and stratigraphic framework of the North Greenland fold belt in Johannes V. Jensen Land, Peary Land. Rapp. Grønlands geol. Unders. 93, 40 pp.

Fränkl, E. 1955: Rapport über die Durchquerung von Nord Peary Land (Nordgrönland) im Sommer 1953. Meddr Grønland 103(8), $61 \mathrm{pp}$.

Haller, J. 1971: Geology of the East Greenland Caledonides. London: Interscience. $413 \mathrm{pp}$.

Håkansson, E. 1979: Carboniferous to Tertiary development of the Wandel Sea Basin, eastern North Greenland. Rapp. Grønlands geol. Unders. 88, 73-83.

Koch, L. 1920: Stratigraphy of Northwest Greenland. Meddr dansk geol. Foren. 5(17), 78 pp.

Pedersen, S. A. S. 1979: Structural geology of central Peary Land, North Greenland. Rapp. Grønlands geol. Unders. 88, 55-62.

Thompson, R. I. 1979: A structural interpretation across part of the northern Rocky Mountains, British Columbia, Canada. Can. J. Earth. Sci. 16 (6), 1228-1241. 